\title{
Persistent infection by adenoviruses
}

\author{
H. G. PEREIRA \\ From the Division of Virology, National Institute for Medical Research, Mill Hill, London
}

Adenoviruses were first described as agents causing spontaneous degeneration in cultures of human adenoids (Rowe, Huebner, Gilmore, Parrott, and Ward, 1953). In a separate study, Hilleman and Werner (1954) described similar viruses in association with acute respiratory illness in military recruits. Subsequent studies by many workers (see review by Sohier, Chardonnet, and Prunieras, 1965) confirmed the above results and firmly established the importance of adenoviruses in the aetiology of acute respiratory illness and their frequent presence in a latent state in human tonsils and adenoids. Furthermore, some adenovirus serotypes were associated with ocular infections, the most important of these being epidemic keratoconjunctivitis caused by adenovirus type 8 (Jawetz, Kimura, Hanna, Coleman, Thygeson, and Nicholas, 1955; Jawetz, Thygeson, Hanna, Nicholas, and Kimura, 1957). Other human diseases with which adenoviruses have been tentatively related include gastroenteritis, rubelliform rashes, acute thyroiditis, cystitis, and hepatitis but the evidence supporting these associations requires substantiation.

Adenoviruses of human origin are divided into 33 serotypes (Blacklow, Hoggan, Austin, and Rowe, 1969) distinguishable on the basis of antigenic composition and some differing from each other in certain biological properties. Types 1, 2, and 5 are the ones most commonly found latently in tonsils and adenoids and sometimes causing respiratory illness among young children, whereas types $3,4,7,7 \mathrm{a}$, 14 , and 21 are mainly associated with outbreaks of respiratory illness in school children or young adults.

In experimental animals, human adenoviruses have been shown to cause fatal infections in newborn hamsters (Pereira, Allison, and Niven, 1962; Samaille, Vivier, Dubois, and Petitprez, 1965), bronchopneumonia in colostrum-deprived piglets (Jennings and Betts, 1962), and asymptomatic latent infections in adult rabbits with persistence of virus in the spleen for periods up to one year (Pereira and Kelly, 1957a and unpublished results; Reddick and Lefkowitz, 1969). Human adenoviruses have also been shown to cause abortive infections leading to tumorigenesis in hamsters and other rodents (Trentin, Yabe, and Taylor, 1962; Huebner, Rowe, and Lane, 1962; Huebner, Casey, Chanock, and Schell, 1965; Girardi, Hilleman, and Swickey, 1964; Pereira, Pereira, and Clarke, 1965; Lacy and Green, 1967) and to transform cells from a variety of animals in vitro (see review by Black, 1968). Primary or continuously cultivated hamster or rat cells have been most commonly used in the transformation studies in vitro but evidence has been presented suggesting that rabbit (Winters and Khoobyarian, 1970) and human (Sultanian and Freeman, 1966) cells may also be abortively infected and transformed by human adenoviruses.

Two possible mechanisms may therefore be invoked to explain latency of adenoviruses in human cells. First, the latent state may result from lytic infection with production of fully active virus which is limited in its replication by immunological or other mechanisms. Alternatively, latency may be a consequence of abortive infection with incorporation of the viral genome into the host cell. The latter would imply that the whole virus genome remains in a partially repressed state for long periods of time but is capable of being changed to a productive state by some unknown inducing mechanism. Incorporation of at least part of the genome of human adenoviruses into mammalian cells has been shown to occur in nonpermissive systems where the virus-cell interaction results in oncogenic transformation with synthesis of virus-specific proteins (Huebner, Rowe, Turner, and Lane, 1963; Pope and Rowe, 1964; Sjögren, Minowada, and Ankerst, 1967) and nucleic acids (Fujinaga and Green, 1966) but without production of infectious virus. It is not known whether lack of infectious virus production in these systems is due to partial incorporation or to partial expression of the viral genome. This situation has been fully substantiated in studies of the interaction between human adenoviruses and cells from hamsters or rats but not when the host cell is of human origin. Adenovirus latency in human cells has not been unquestionably associated with oncogenic transformation and in most systems investigated it has been possible to recover infectious virus from the population of infected cells. This situation will be referred to as persistent productive infection as 
opposed to non-productive infections observed in connexion with oncogenic transformation.

The mechanism of persistent productive infections by adenoviruses has been studied both in human and in rabbit cells. Many investigators have reported the finding of adenovirus in surgically removed human tonsils and adenoids. From the facts that the serotypes 1,2 , and 5 most frequently found in this situation cause primary infections early in life (Rowe, Huebner, and Bell, 1957) and can still be recovered from adenoids in older age groups (Rowe, Huebner, Hanley, Ward, and Parrott, 1955; Evans, 1958; Israel, 1962) suggest that latent infections may persist for many years. All reports of recovery of virus from tonsils or adenoids refer to the fact that, with very few exceptions, infective virus cannot be detected directly in tissue extracts. Its presence can only be revealed after cultivation in vitro of the tonsil or adenoid tissues for varying periods.

A detailed study of human adenoid cells naturally or experimentally infected by adenoviruses has been conducted by Strohl and Schlesinger $(1965 \mathrm{a}, \mathrm{b})$ who concluded that failure to detect virus in tissue extracts was due to the small proportion $\left(1\right.$ in $\left.10^{7}\right)$ of infected cells in the original tissues. This, plus the considerable asynchrony of the infectious cycle, would also explain the long delay sometimes observed before the appearance of viral infectivity in cultures of latently infected tissues. A similar conclusion had previously been reached by Evans (1958). Another factor possibly involved in preventing or delaying the demonstration of infectious virus in this system might be the presence of virus-neutralizing antibody in the tissues of origin. Strohl and Schlesinger (1965b) observed, however, that there is no correlation between the presence or absence of neutralizing activity in tissue extracts and the ease with which virus could be recovered. On the other hand, it has been demonstrated by Ginsberg (1958) that persistent adenovirus infection of cultivated human cells requires the presence of antibody or other inhibitors found in human sera.

Studies on the mechanism of persistent adenovirus infection have also been conducted in rabbit cells infected either in vivo or in vitro (Ankudas and Khoobyarian, 1962; Reddick and Lefkowitz, 1969; Winters and Khoobyarian, 1970; Pereira, unpublished results). Adult rabbits given a single dose of virus showed antibody responses developing within a week, reaching peak titres soon after and slowly declining but remaining at detectable levels for up to 12 months (Lefkowitz, Williams, Howard, and Sigel, 1966; Reddick and Lefkowitz, 1969; Pereira and Kelly, 1957a; Pereira, unpublished results). Virus could be regularly demonstrated in the spleen and lymph nodes of infected animals up to at least 12 months after infection. In our own experiments, the ease of recovering virus from the spleens of infected animals was inversely correlated with the level of serum antibody titres at the time when the tissue was obtained. Thus, demonstration of infectious virus by direct inoculation of spleen homogenates into susceptible (HeLa) cell cultures was only achieved either very soon after infection, before the onset of antibody response, when the recovered virus may represent surviving inoculum, or very late when serum antibody levels had shown some decline (see Table). Another indication that antibody may have been at least partly responsible for the failures to demonstrate virus in spleen homogenates was the fact that virus could sometimes be demonstrated in trypsinized and washed cells from tissues which gave

\begin{tabular}{|c|c|c|c|c|c|c|}
\hline \multirow[t]{2}{*}{ Animal No. } & \multirow{2}{*}{$\begin{array}{l}\text { Time after } \\
\text { Inoculation (days) }\end{array}$} & \multicolumn{2}{|c|}{ Antibody Titres } & \multicolumn{3}{|l|}{ Virus Isolation } \\
\hline & & $V N^{1}$ & $C F^{2}$ & Tissue Homogenate & Trypsinized Cells & Tissue Cultures \\
\hline 1 & 3 & 50 & 10 & + & $\mathbf{N T}^{3}$ & + \\
\hline 2 & 6 & 800 & 20 & - & $\mathrm{NT}$ & + \\
\hline 3 & 13 & 800 & 20 & - & NT & + \\
\hline 4 & 20 & 1600 & 80 & - & NT & + \\
\hline 5 & 27 & 800 & 30 & - & NT & + \\
\hline 7 & 55 & 3200 & 320 & - & - & + \\
\hline 8 & 60 & $\mathbf{N T}^{3}$ & 60 & - & + & + \\
\hline 9 & 97 & 1600 & 120 & - & + & + \\
\hline 10 & 126 & 400 & 30 & - & + & + \\
\hline 11 & 210 & 200 & 15 & - & NT & + \\
\hline 12 & 290 & 100 & 30 & + & + & + \\
\hline
\end{tabular}

Table Antibody titres and virus isolations from spleens of rabbits killed at varying times after intravenous inoculation with $10^{9} 0 \mathrm{TCD} \mathrm{D}_{50}$ of adenovirus type 5

\footnotetext{
Figures represent reciprocals of serum dilutions corresponding to $50 \%$ titration endpoint

IVN = virus neutralization

${ }^{2} \mathrm{CF}=$ complement fixation

${ }^{2} \mathrm{NT}=$ not tested

$10^{7}$ spleen cells dispersed by trypsin, repeatedly washed and frozen and thawed three times before inoculation into HeLa cell cultures.
} 
negative results as homogenates. Our results differ somewhat from those reported by Reddick and Lefkowitz who managed to recover virus directly from tissue homogenates more frequently than we did. The same workers observed that spleen and lymph node cells from infected animals were able to synthesise specific antibody in vitro when exposed to antigen before cultivation.

Persistent adenovirus infection of rabbit cells in vitro can be maintained for long periods in the absence of virus-neutralizing antibody (Winters and Khoobyarian, 1970; Pereira, unpublished results). In our experiments, rabbit spleen cells derived from infected animals or inoculated with virus after explanation were maintained for several months with minimal cytopathic effects but constant production of infectious virus. In all instances, however, the cultures eventually showed complete degeneration, coincident with increased virus production, and could not be propagated indefinitely. On the other hand, Winters and Khoobyarian (1970) observed a gradual decline in virus production leading to an abortive state with permanent synthesis of viral antigens but not of infectious virus. Similar results have been reported by Sultanian and Freeman (1966) with human cells.

From the above result;, and from those reported by Strohl and Schlesinger (1965b) with human adenoids, it is impossible to draw firm conclusions regarding the role of antibodies in the so-called 'masked' state of virus in latently infected tissues. Neither can it be decided whether abortive as well as lytic infections are involved in the phenomenon. It is likely, however, that 'masking' results from a combination of factors, including low level of infection with a high degree of asynchrony and possibly virus inhibition by antibody or other factors. In neither system discussed above, namely, human adenoids and rabbit lymphoid tissues, is it necessary to postulate the operation of abortive mechanisms to explain viral latency.

\section{Epidemiological Implications}

It has been repeatedly observed that the adenovirus serotypes $(1,2$, and 5) most frequently found in surgically recovered tonsils and adenoids are those which cause infections in early infancy rather than the types $(3,4,7,7 \mathrm{a}, 14$, and 21$)$ associated with epidemics of respiratory or other illnesses in school children or adults. Instances of isolation of the latter serotypes from adenoids have mostly been described following outbreaks of infection in the populations involved (Rowe and Huebner, 1956), and in one report (Pereira and Kelly, 1957b) adenovirus type $7 \mathrm{a}$ was isolated from the adenoids of a child who had been primarily infected with the same virus four months earlier. These findings suggest that latently infected subjects may represent a widespread source of the serotypes which cause primary infections early in life leading to immunity and consequent depletion of susceptible persons at older ages. The same would not apply to the epidemic serotypes.

\section{References}

Ankudas, M. M., and Khoobyarian, N. (1962). Rabbit heart cell culture, strain RHF-1 II. Behavior of adenovirus types 1 to 4 . J. Bact., 85, 1287-1291.

Black, P. H. (1968). The oncogenic DNA viruses. A review of in vitro transformation studies. Ann. Rev. Microbiol., 22, 391-426.

Blacklow, N. R., Hoggan, M. D., Austin, J. B., and Rowe, W. P. (1969). Observations on two new adenovirus serotypes with unusual antigenic characteristics. Amer. J. Epidemiol., 90, 501-505.

Evans, A. S. (1958). Latent adenovirus infections of the human respiratory tract. Amer. J. Hyg., 67, 256-266.

Fujinaga, K., and Green, M. (1966). The mechanism of viral carcinogenesis by DNA mammalian viruses. Virus specific RNA in polyribosomes of adenovirus tumor and transformed cells. Proc. nat. Acad. Sci. (Wash)., 55, 1567.

Ginsberg, H. S. (1958). A consideration of the role of serums in inhibitors in latency and analysis of persistent adenovirus infection of mammalian cells. In Symposium on Latency and Masking in Viral and Rickettsial Infections, edited by D. L. Walker, R. P. Hanson, and A. S. Evans, p. 157-168. Burgess, Minneapolis, Minnesota.

Girardi, A. J., Hilleman, M. R., and Zwickey, R. E. (1964). Tests in hamsters for oncogenic quality of ordinary viruses including adenovirus type 7. Proc. Soc. exp. Biol. (N.Y.), 115, 1141-1150.

Hilleman, M. R., and Werner, J. H. (1954). Recovery of new agent from patients with acute respiratory illness. Proc. Soc. exp. Biol. (N.Y.), 85, 183-188.

Huebner, R. J., Casey, M. J., Chanock, R. M., and Schell, K. (1965). Tumors induced in hamsters by a strain of adenovirus type 3 : sharing of tumor antigens and 'neoantigens' with those produced by adenovirus type 7 tumors. Proc. nat. Acad. Sci. (Wash.), 54, 381-388.

Huebner, R. J., Rowe, W. P., and Lane, W. T. (1962). Oncogenic effects in hamsters of human adenovirus types 12 and 18. Proc. nat. Acad. Sci. (Wash.), 48, 2051-2058.

Huebner, R. J., Rowe, W. P., Turner, H. C., and Lane, W. T. (1963). Specific adenovirus complement-fixing antigens in virus-free hamster and rat tumors. Proc. nat. Acad. Sci. (Wash.), 50, 379-389

Israel, M. S. (1962). The viral flora of enlarged tonsils and adenoids. J. Path. Bact., 84, 169-176.

Jawetz, E., Kimura, S. J., Hanna, L., Coleman, V. R., Thygeson, P., and Nicholas, A. (1955). Studies on the etiology of epidemic keratoconjunctivitis. Amer. J. Ophthal., 40 (5/2), 200-211.

Jawetz, E., Thygeson, P., Hanna, L., Nicholas, A., and Kimura, S. J. (1957). The etiology of epidemic keratoconjunctivitis. Amer. J. Ophthal., 43 (4/2), 79-83.

Jennings, A. R., and Betts, A. O. (1962). Human adenoviruses in pigs. Ann. N.Y. Acad. Sci., 101, 485-492.

Lacy, S., and Green, M. (1967). The mechanism of viral carcinogenesis by DNA mammalian viruses: DNA-DNA homology relationships among the 'weakly' oncogenic human adenoviruses. J. gen. Viro!., 1, 413-418.

Lefkowitz, S. S., Williams, J. A., Howard, B. E., and Sigel, M. M. (1966). Adenovirus antibody measured by the passive hemagglc tination test. J. Bact., 91, 205-212.

Pereira, H. G., Allison, A. C., and Niven, J. S. F. (1962). Fatal infection of new-born hamsters by an adenovirus of human origin. Nature (Lond.), 196, 244-245.

Pereira, H. G., and Kelly, B. (1957a). Latent infection of rabbits by adenovirus type 5. Nature (Lond.), 180, 615-616.

Pereira, H. G., and Kelly, B. (1957b). Studies on natural and experimental infections by adenoviruses. Proc. roy. Soc. Med., 40, 755-757.

Pereira, M. S., Pereira, H. G., and Clarke, S. K. R. (1965). Human 
adenovirus type 31. A new serotype with oncogenic properties. Lancet, 1, 21-23.

Pope, J. H., and Rowe, W. P. (1964). Immunofluorescent studies of adenovirus 12 tumors and of cells transformed or infected by adenoviruses. J. exp. Med., 120, 577-588.

Reddick, R. A., and Lefkowitz, S. S. (1969). In vitro immune responses of rabbits with persistent adenovirus type 5 infection $J$. Immunol., 103, 687-694.

Rowe, W. P., and Huebner, R. J. (1956). Present knowledge of the clinical significance of the adenoidal-pharyngeal-conjunctival group of viruses. Amer. J. trop. Med., 5, 453-460.

Rowe, W. P., Huebner, R. J., and Bell, J. A. (1957). Definition and outline of contemporary information on the adenovirus group. Ann. N.Y. Acad. Sci., 67, 255-261.

Rowe, W. P., Huebner, R. J., Gilmore, L. K., Parrott, R. H., and Ward, T. G. (1953). Isolation of a cytopathogenic agent from human adenoids undergoing spontaneous degeneration in tissue culture. Proc. Soc. exp. Biol. (N.Y.), 84, 570-573.

Rowe, W. P., Huebner, R. J., Hartley, J. W., Ward, T. G., and Parrott, R. H. (1955). Studies of the adenoidal-pharyngeal-conjunctival (APC) group of viruses. Amer. J. Hyg., 61, 197-218.

Samaille, J., Vivier, E., Dubois, D., and Petitprez, A. (1965). Etude en microscopie electronique de la multiplication des adenovirus d'origine humaine dans le foic du hamster. C.R. Acad. Sci.
(Paris), 260, 1030-1033.

Sjögren, H. O., Minowada, J., and Ankerst, J. (1967). Specific transplantation antigens of mouse sarcomas induced by adenovirus type 12. J. exp. Med., 125, 689-701.

Sohier, R., Chardonnet, Y., and Prunieras, M. (1965). Adenoviruses status of current knowledge. Progr. med. Virol., 7, 253-325.

Strohl, W. A., and Schlesinger, R. W. (1965a). Quantitative studies of natural and experimental adenovirus infections of human cells. 1. Characteristics of viral multiplication in fibroblasts derived by long-term culture from tonsils. Virology, 26, 199-207.

Strohl, W. A., and Schlesinger, R. W. (1965b). Quantitative studies of natural and experimental adenovirus infections of human cells. II. Primary cultures and the possible role of asynchronous viral multiplication in the maintenance of infection. Virology, 26, 208-220.

Sultanian, I. V., and Freeman, G. (1966). Enhanced growth of human embryonic cells infected with adenovirus 12. Science, 145, 665-667.

Trentin, J. J., Yabe, Y., and Taylor, G. (1962). The quest for human cancer viruses. Science, 137, 835-841.

Winters, W. D., and Khoobyarian, N. (1970). Fate of adenovirus types 2 and 12 in infected serial cultures of non-primate origin. J. gen. Virol., 8, 95-104. 